\title{
Expression of death-related genes and reactive oxygen species production in Skeletonema tropicum upon exposure to the polyunsaturated aldehyde octadienal
}

\author{
Alessandra A. Gallina, ${ }^{1 \#}$ Chih-Ching Chung, ${ }^{2,3}$ Raffaella Casotti ${ }^{1 *}$ \\ ${ }^{1}$ Stazione Zoologica Anton Dohrn di Napoli, Villa Comunale, 80121 Naples, Italy; ${ }^{2}$ Institute of Marine Environmental Chemistry and \\ Ecology, National Taiwan Ocean University, Keelung 20224, Taiwan, China; ${ }^{3}$ Center of Excellence for the Oceans, National Taiwan \\ Ocean University, Keelung 20224, Taiwan, Republic of China \\ "Present address: Department of Biology, Colorado State University, Fort Collins, CO 80523, USA \\ *Corresponding author: raffaella.casotti@szn.it
}

\begin{abstract}
The effects of $4 E / Z$-octadienal (OCTA) on $S c D S P-1$ and $S c D S P-2$ gene expression and reactive oxygen species (ROS) production were investigated in the marine diatom Skeletonema tropicum (formerly costatum) using qRTPCR and flow cytometry. ScDSP-1 and $S c D S P-2$ genes have been previously shown to be involved in cell death in ageing cells and in response to photosynthetic stress. OCTA induced a differential, concentration-dependent $D S P$ gene expression associated to ROS production, 821.6 and 97.7 folds higher for $S c D S P$ 1 and $S c D S P-2$, respectively. Among the concentrations tested, only $8 \mu \mathrm{M}$ OCTA, which caused a reduction of $50 \%$ in cell concentrations at $24 \mathrm{~h}$, was able to elicit an expression pattern consistent with a signalling role. Interestingly, only intermediate levels of reactive oxygen species (ROS) (i.e., $1.5 \pm 0.1$ increase) were observed to be elicited by such concentration. These results suggest that ROS are key components of the molecular cascade triggered by polyunsaturated aldehydes (PUA) and leading to cell death. This could have implications for bloom final stages at sea, where PUA may act as effectors of diatom population dynamics through ROS acting as modulators.
\end{abstract}

Key words: Diatom; chemical ecology; bloom evolution; Programmed cell death; ROS.

Received: July 2015. Accepted: October 2015.

\section{INTRODUCTION}

Marine diatoms are some of the most successful groups of unicellular eukaryotic photosynthetic organisms, forming massive blooms in coastal and open waters and having a key role in global marine primary production (Armbrust, 2009). Elucidating the mechanisms that regulate diatom bloom dynamics and mainly their decay determinants is therefore fundamental to understand nutrient and carbon cycling so as energy flow at the global as well as the local scale.

Programmed cell death (PCD) is an active, self-controlled death mechanism well known in higher organisms which has been also detected in unicellulars (Bidle et al., 2007; Segovia, 2011). However, its occurrence in unicellular organisms is still considered a matter of ongoing debate (Deponte, 2008; Jimenez et al., 2009), and the specific mode of action in which PCD is initiated remains to be elucidated. PCD has been suggested to act in phytoplankton populations to eliminate aged cells and to reduce population size in order to cope with nutrient limitation, for instance, in the final stages of blooms (Bidle and Falkowski, 2004; Vardi et al., 1999, 2006, 2007). After a certain threshold of limitation of environmental factors (mainly nutrients), PCD induces the massive decay of the bloom, sometimes through massive production of resting or resistance stages
(Ellegaard et al., 2013; McQuoid et al., 2002). These factors include nitrogen and light limitation (Berges and Falkowski, 1998), iron starvation (Bidle and Bender, 2008; Thamatrakoln et al., 2012), virus infection (Bidle et al., 2007; Vardi et al., 2009), $\mathrm{CO}_{2}$ limitation (Vardi et al., 1999) and several secondary metabolites (Cervia et al., 2009; Costas et al., 1993). Reactive oxygen species (ROS) are often involved in inducing $\mathrm{PCD}$ in reaction to a stress factor in a wide range of organisms and cell lines, from bacteria to mammalians and plants (Andrianasolo et al., 2007; Jones, 2008; Kuwabara et al., 2008; Lam, 2008; Rockenfeller and Madeo, 2008; Scherz-Shouval and Elazar, 2007), mainly at intermediate concentrations. In fact, several cell reactions to ROS strongly depend upon the ROS concentration and may range from production of antioxidant compounds to necrotic cell death (Chandra et al., 2000), or PCD (Costas et al., 1993; Vardi et al., 2009). Apart from ROS concentrations, several variables come into play by modulating and regulating the cell response to ROS. These include the cell type, the stress type, its magnitude and its duration in time (Martindale and Holbrook, 2002).

Different case studies report the co-occurrence of ROS and PCD in marine phytoplankton and suggest a correlation between them (Butow et al., 1997; Segovia and Berges, 2009; Vardi et al., 1999). In the dinoflagellate Peridinium gatunense, PCD leading to the collapse 
of the algal population is mediated by oxidative stress induced by carbon dioxide $\left(\mathrm{CO}_{2}\right)$ limitation (Vardi et al., 1999). Similarly, ROS-mediated cell death was observed at the end of a bloom of the same species, despite an increase in antioxidant activity (Butow et al., 1997). PCDlike cell death concomitant with accumulation of ROS is also reported to be induced by the toxic cyanobacterium Microcystis sp. (Vardi et al., 2002), or $\mathrm{H}_{2} \mathrm{O}_{2}$ (Vardi et al., 2007). In the chlorophyte Dunaliella tertiolecta, dark-induced PCD, involving the activity of caspase-like enzymes has been linked to an increase in ROS production (Segovia and Berges, 2009). In the prymnesiophyte Emiliana huxley viral infection has been associated to an enhanced production of ROS, possibly leading to PCD (Evans et al., 2006).

Interestingly, the secondary metabolite Euplotin C derived from the marine ciliated protist Euplotes crassus, is found to induce PCD in the congeneric Euplotes vannus, which does not produce this metabolite (Cervia et al., 2009). This suggests that specific secondary metabolites can play an ecological role in broadening phytoplankton niche size through different mechanisms, including PCD (Cervia et al., 2009).

In the marine diatom Phaeodactylum tricornutum, the exposure to diatom-derived secondary metabolites, polyunsaturated aldehydes (PUA), results in an altered expression of metacaspases through the overexpression of a gene associated to NO generation (Vardi et al., 2008). In the marine diatom Thalassiosira weissflogii, PUA were shown to induce PCD-like cell death, suggesting for a role in activating the cell death cascade, therefore regulating population dynamics and species succession (Casotti et al., 2005). In Phaeodactylum tricornutum it is speculated that a sophisticated stress surveillance system exists, involving NO and Calcium, in response to PUA, which could lead to bloom termination and population-level cell death at specific PUA concentrations (Vardi et al., 2006). Even PUA precursors, the polyunsaturated fatty acids (PUFAs), have been reported to inhibit growth of Candida albicans and Candida dubliniensi by inducing ROS accumulation and consequent PCD (Thibane et al., 2012).

In the marine diatom Skeletonema tropicum (formerly costatum) two genes have been identified, coding for two identical Ca-regulated proteins, named $S$. costatum DeathSpecific Proteins ( $S c D S P-1$ and $S c D S P-2)$ (Chung et al., 2005), which are both composed of a transmembrane domain and a pair of EF-hand motifs (Luan et al., 2002; Means and Dedman, 1980). Both ScDSP gene expressions were shown to be strongly upregulated in aging cells and also during light stress. Their expression is correlated to DNA fragmentation, suggesting for a possible role of the encoded protein in the signal transduction of stress to the cell death machinery (Chung et al., 2005, 2008). In particular, $S c D S P$ expression has been related to the blockage of the electron flow between PSII and cytochrome $b_{6} f$ and it was found to be NO dependent (Chung et al., 2008). Moreover, two $D S P$-like proteins (TpDSP1 and TpDSP2), have been recently identified in the marine diatom Thalassiosira pseudonana and have been shown to be upregulated both under iron limitation and starvation, suggesting for a role in Fe-induced stress and consequent death (Thamatrakoln et al., 2012). However, they have also recently been shown to enhance growth under Fe limitation and to be controlled by light intensity (Thamatrakoln et al., 2013).

In this study we report the gene expression of the two death-related genes $S c D S P-1$ and $S c D S P$ - 2 in ST exposed to the polyunsaturated aldehyde octadienal, and relate it to ROS production. The overall aim is to relate cell death to chemical stress induced by PUA and to advance hypotheses on bloom decay mechanisms at sea.

\section{METHODS}

\section{Experimental setup and cultures}

A unialgal culture of Skeletonema tropicum Cleve (formerly costatum) was grown at $23^{\circ} \mathrm{C}$ on a $12 \mathrm{~h}-12 \mathrm{~h}$ lightdark cycle under a photon flux density of $110 \mu \mathrm{mol}$ quanta $\mathrm{m}^{-2} \mathrm{~s}^{-1}$ (Chung et al., 2005). Natural seawater, amended with f/2 nutrients (Guillard, 1975) was used as medium. For gene expression measurements, S. tropicum was grown in $10 \mathrm{~L}$ polycarbonate carboys (Nalgene). When the culture reached the late exponential phase of growth (LE, Fig. 1), cells were transferred into $2 \mathrm{~L}$ polycarbonate bottles (Nalgene) and treated with different concentrations of $4 E / Z$-octadienal (OCTA) or $\mathrm{H}_{2} \mathrm{O}_{2}$. Samples were collected at $1,2,3,4,5$ and $1,2,3,4,12$ days since the beginning of the

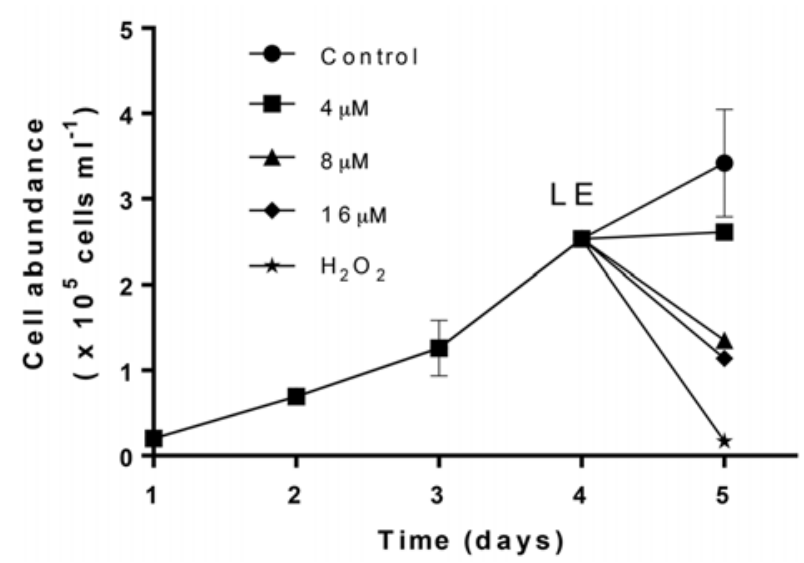

Fig. 1. Effect of OCTA and $\mathrm{H}_{2} \mathrm{O}_{2}$ on cell concentrations of $S$. tropicum. LE is the time point indicated as Late Exponential growth phase. Data are means of triplicates $\pm \mathrm{SD}$. When the bar is not visible, it is smaller than the symbol. 
experiment for cell counts and total RNA extraction, respectively. Cell concentrations were determined by using a Sedgwick-Rafter counting chamber (Hausser Scientific Partnership). At least 200 cells from each sample were counted using a light microscope (BX60; Olympus, Center Valley, USA) at $200 \times$ magnification. Growth rates were calculated using the following equation:

$\mu=\ln \left[\left(N_{l} / N_{0}\right) / \mathrm{t}\right]$

where $N_{0}$ and $N_{l}$ are cell density at the start and the end of the growth period, and $t$ is the time between measurements (in days). Since no dead $v s$ alive cells assay has been used, it is possible that the cells counts reported in the study might include damaged or dying cells.

Gene expression experiments were performed using three OCTA concentrations, namely the concentration which caused a reduction of $50 \%$ in cell concentration at $24 \mathrm{~h}$, half this concentration and twice this concentration (4, 8 and $16 \mu \mathrm{M})$. For ROS detection, three independent cultures were grown in $1 \mathrm{~L}$ glass flasks until the late exponential growth phase. Cells were harvested and directly exposed to the same concentrations of OCTA used for gene expression measurements and analysed through flow cytometry as described below. The controls were dyeloaded samples processed exactly as the other samples except for PUA inoculation.

Each experiment was performed at least twice, but generally three times, i.e. the data presented are the results of biological replicates.

\section{Chemicals}

The PUA used in this study was $2 E, 4 E / Z$-octadienal (OCTA, from Sigma Aldrich Inc. Milan, Italy). This was chosen because it is the main and most commonly produced PUA by diatoms, and, in particular, by Skeletonema spp. (Wichard et al., 2005). The concentrations used were chosen accounting for multiples of the concentration causing a reduction of $50 \%$ in cell concentrations at $24 \mathrm{~h}$, as empirically determined for $S$. tropicum (data not shown) resulting to be $8 \mu \mathrm{M}$. The reference value of $8 \mu \mathrm{M}$ has been chosen also based on Ribalet et al., (2007), where 8 $\mu \mathrm{M}$ represented the $\mathrm{EC}_{50}$ for growth in the congeneric species $S$. marinoi. OCTA working solutions were dissolved in HPLC-grade pure Methanol (JT Baker, Phillipsburg, NJ, USA) at room temperature. Since Methanol can be toxic, it was tested on growing cultures and cultures showed no reaction up to 7 microliters per mL. Subsequently, and conservatively, no more than 4 microliters of Methanol plus OCTA were ever inoculated into the cultures. Before incubation, the exact OCTA concentration in the working solution was assessed spectrophotometrically (Hewlett-Packard 8453- Hewlett-Packard Co., Palo Alto, CA, USA) by measuring absorption at $274 \mathrm{~nm}$ and a specific molar absorption coefficient of 31,000 (Pippen and Nonaka, 1958). Hydrogen peroxide $\left(\mathrm{H}_{2} \mathrm{O}_{2}, 30\right.$ wt. \% from Sigma Aldrich, Milan, Italy) was used as positive control, after dilution $1 / 200$ in filtered seawater and added to samples as a $50 \mu \mathrm{L}: 1 \mathrm{~mL}$ ratio.

The ROS scavenger, 4-Hydroxy-2,2,6,6-tetramethylpiperidine 1-oxyl (TEMPOL, Sigma-Aldrich, Milan, Italy) was used as negative control, so as sodium diethyldithiocarbamate trihydrate (DETC, Sigma-Aldrich), an inhibitor of superoxide dismutase (SOD) at a final concentration of $5 \mathrm{mM}$ and $1 \mathrm{mM}$, respectively, in filtered sea water (FSW). Samples with DETC were incubated for 120 min prior to PUA addition. The ROS-sensitive dye dihydrorodamine 123 (DHR, Molecular Probes, Leiden, NL) (5 mM stock in DMSO) was used to monitor ROS production at the single-cell level. DHR can be oxidized by different ROS, including hydrogen peroxide $\left(\mathrm{H}_{2} \mathrm{O}_{2}\right)$ and peroxynitrite $\left(\mathrm{ONOO}^{-}\right)$, to form the fluorescent derivative rhodamine 123 (excitation WL 492-495 nm, emission $\mathrm{WL}=517-527 \mathrm{~nm}$ ), and is commonly used to investigate oxidative stress in vivo (Ischiropoulos et al., 1999). DHR has been previously used in different microalgal species to measure oxidative burst (Jamers et al., 2009; Vardi et al., 1999). Samples were incubated with both $10 \mu \mathrm{M}$ DHR and PUA in the dark at room temperature and analysed using flow cytometry (see below).

\section{Flow cytometry}

To quantify ROS production in vivo, a flow cytometer (FACScalibur, Becton Dickinson, Palo Alto, CA, USA) equipped with a 488-nm laser as excitation source and filtered sea water as sheath was used. A 530/30-nm beampass emission filter was used for detection of DHR-derived green fluorescence. Both the sheath fluid and the sample velocity $\left(65 \mu \mathrm{Lmin}^{-1}\right)$ were kept constant during all the experiments. As a trigger signal, red fluorescence was used with a threshold at channel 52. Red fluorescence was collected through a 650-nm long-pass filter and was also used as a proxy for chlorophyll cell fluorescence. Fluorescent beads (Coulter FlowSet Fluorospheres, Beckman Coulter, Fullerton, CA, USA) were used as internal standard. Green fluorescence values were normalized to the green fluorescence of the beads, and all data were expressed as fold changes of green fluorescence relative to the control values. Data acquisition ( $10^{4}$ cells on average for each sample) was performed using CellQuest software (Becton-Dikinson). Data analysis was performed using FCS4 Express (De Novo Softwares, Los Angeles, CA, USA).

\section{Total RNA extraction}

Two-hundred $\mathrm{mL}$ of culture were collected through a filtration system using a $2-\mu \mathrm{m}$ pore size polycarbonate filter (Nucleopore; Whatman, Maidstone, UK), placed over a 
GF/F glass microfiber filter (Whatman). Filtration never lasted longer than $30 \mathrm{~min}$. Cells were then resuspended in $0.7 \mathrm{~mL}$ guanidine isothiocyanate buffer (RLT buffer, Qiagen, Valencia, CA, USA) containing $1 \% \beta$-mercaptoethanol (Sigma Aldrich, St. Louis, MO, USA), immediately frozen at $-80^{\circ} \mathrm{C}$, and stored for a few days. After disrupting the cells by sonication on ice (Sonicator ultrasonic processor XL, Heat System Ultrasonics, Farmingdale, NY, USA), total RNA was extracted using the silica-membrane spin column included in the RNeasy Plant Mini Kit (Qiagen). The residual genomic DNA was removed by an additional treatment with the RNase-Free DNase Set (Qiagen) according to the manufacturer's instruction. Total RNA concentration and purity were determined with a spectrophotometer (ND-100; NanoDrop Technologies, Wilmington, DE, USA) by measuring absorption at 260 and $280 \mathrm{~nm}$.

\section{Reverse transcription and Real time quantitative polymerase chain reaction}

One $\mu \mathrm{g}$ of total RNA was treated with DNase I and reverse transcribed into first-strand complementary DNA (cDNA) fragments by using random hexamer oligonucleotides and the High Capacity cDNA Reverse Transcription Kit (Applied Biosystems, Foster City, CA, USA). The conditions for the retro-transcription were set as in Chung et al. (2005): $25^{\circ} \mathrm{C}$ for $10 \mathrm{~min}, 37^{\circ} \mathrm{C}$ for $120 \mathrm{~min}$, and $85^{\circ} \mathrm{C}$ for $5 \mathrm{~min}$. Real time quantitative polymerase chain reactions (Q-PCR) were performed using $2 \times$ SYBR Green PCR master mix (Applied Biosystems) with $250 \mathrm{nM}$ of each of the forward and reverse primers. The nucleotide sequences of all primer pairs used in the Q-PCRs are indicated in Tab. 1. The GeneAmp 7000 sequence detection system (Applied Biosystems) was used to carry out all the reactions. The threshold cycle at which the fluorescence intensity exceeded a preset threshold was used to calculate the target gene mRNA and 18S rRNA expression levels. The RNA molar ratio of ScDSP mRNA and 18S rRNA was calculated using the formula described in Chung et al., (2005), and the data normalized to the control values. The levels of $S c D S P$ mRNA expression were expressed as fold changes of mRNA abundance relative to the control. All data reported are means of three technical replicates but the experiments were repeated at least twice.

\section{Statistical analyses}

Pairwise comparisons among treatments and control were assessed by Student's $t$-test using the Excel spreadsheet (Microsoft, Redmond, Washington, MA, USA).

\section{RESULTS AND DISCUSSION}

Cultures were affected by OCTA exposure. $16 \mu \mathrm{M}$ OCTA reduced cell concentrations to $51.17 \%$ of initial val- ues after $24 \mathrm{~h}$ (Fig. 1; Tab.2). $\mathrm{H}_{2} \mathrm{O}_{2}$ also strongly affected cell concentrations which decreased to $50 \%$ as early as 2 $\mathrm{h}$ after inoculation and to zero $24 \mathrm{~h}$ later (Fig. 1).

$S c D S P-1$ and $S C D S P-2$ gene expression and ROS levels increased in $S$. tropicum cultures exposed to different concentrations of OCTA. A peak in ScDSP-1 and ScDSP2 expression was visible as early as $1 \mathrm{~h}$ after exposure and its intensity for cells in LE exposed to the concentration of $8 \mu \mathrm{M}$ OCTA was ca. 822 and 98 folds that in the control for $S c D S P-1$ and $S c D S P$-2, respectively (Fig. 2 a,b). Gene expression decreased afterward and showed no further peak until the end of the experiment. In the same strain, an increase in $S c D S P$ expression has been previously reported when cultures entered senescence (Chung et al., 2005) and also in response to a light stress involving the blockage of electron flow at the level of the photosystem II (Chung et al., 2008). The latter also involved NO increase in the gene regulation and involvement of a PCD machinery (Chung et al., 2008). Overall, these results provide evidence that the $D S P$ genes have a role in regulating the molecular mechanism of mortality in S. tropicum under stress.

In our experiments, gene expression was highest at the concentrations where ROS production was intermediate, suggesting that there exists a threshold for the activation of the two death-related genes investigated. A peak in ROS was observed 20 min after inoculation with OCTA (Fig. 3), followed by a decrease. The intensity of the peak

Tab. 1. Primer pairs used for the qRT PCR reactions, as in Chung et al. (2008).

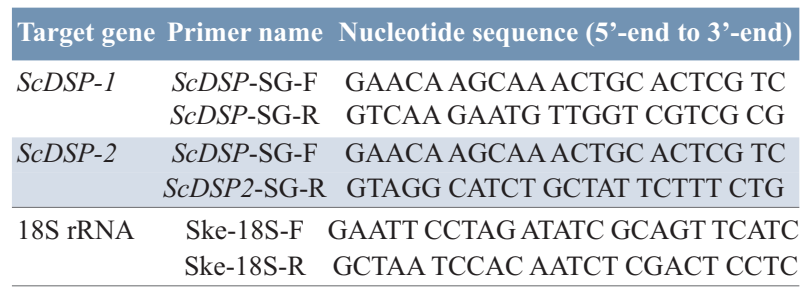

Tab. 2. Effect of OCTA on growth rate of S. tropicum cultures after

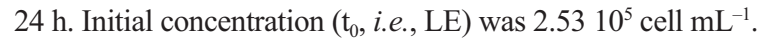

\begin{tabular}{ccc} 
& Growth rate $\left(\right.$ day $\left.^{-1}\right)$ \\
& Concentration $(\mu M)$ & LE \\
OCTA $^{\circ}$ & 0 & $0.30 \pm 0.10$ \\
4 & $0.03 \pm 0.08$ \\
$8^{*}$ & $-0.63 \pm 0.39$ \\
16 & $-0.80 \pm 0.22-$ \\
$16 \mathrm{H}_{2} \mathrm{O}_{2}$ & $2.70 \pm 0.35$ \\
\hline
\end{tabular}

LE, Late exponential growth phase (as in Fig. 1); ${ }^{\circ} 2 E, 4 E / Z$-octadienal; * concentration causing a reduction of $50 \%$ in cell concentrations at 24 $\mathrm{h}$ (see text). Data are means $\pm \mathrm{SD}, \mathrm{n}=3$. 
was PUA concentration-dependent, and was highest for $16 \mu \mathrm{M}$ OCTA $(1.9 \pm 0.2$ increase; $\mathrm{P}<0.001, \mathrm{n}=3)$. Both the ROS scavenger Tempol and the SOD inhibitor DETC reduced the intensity of the peak, therefore supporting the conclusion that the peak was really due to an increase of ROS. No increase in DHR-derived green fluorescence was observed when methanol only was added to the cultures, excluding an artifact due to the solvent used (data not shown). Hence, it is suggested that cell death is triggered in S. tropicum only by specific PUA concentrations, which are those causing a reduction of $50 \%$ in cell concentrations at $24 \mathrm{~h}(8 \mu \mathrm{M}$ OCTA $)$. This is supported by the observation that $8 \mu \mathrm{M}$ OCTA induced intermediate levels of ROS production (1.5 \pm 0.1 increase in LE cultures), while a higher concentration (16 $\mu \mathrm{M}$ OCTA) elicited a considerably lower ScDSP expression, even though it induced a higher ROS production (1.9 \pm 0.2 increase). This could be related to different molecular signals triggered in the two cases.

In our experiments, while the addition of $\mathrm{H}_{2} \mathrm{O}_{2}$ to the cultures induced an increased DSP gene expression, the levels were not as high as those elicited by OCTA, even though the DHR-ROS derived green fluorescence was the highest observed ( $7.5 \pm 0.9$ times the control at $40 \mathrm{~min}$ after exposure, not shown). This suggests that ROS could be important modulators in the pathway leading to cell death. Even though evidence for the occurrence of apoptotic-like features in S. tropicum in response to PUA was not provided in this study, it has been previously reported that PUA are able to induce apoptotic-like cell death in the marine diatom Thalassiosira weissflogii (Casotti et al.,
2005). In addition, in the marine diatom Phaeodactylum tricornutum PUA exposure induced overexpression of a gene associated to NO production (designated as PtNOA), that resulted in an altered expression of superoxide dismutase and an increased metacaspase activity, which are known factors in the stress responses and PCD pathway (Vardi et al., 2008). Indeed, in our OCTA-exposed S. tropicum cultures, PUA had a toxic effect drastically affecting growth and inducing cell death.

ROS are generally indicated in the literature as PCDinducing factors (Aldsworth et al., 1999; Simon et al., 2000). However, we suggest that a difference exists between the intracellular effectors of a PCD-like process (e.g., NO and ROS), and other factors and stimuli that, causing an alteration of $\mathrm{NO}$ and ROS, are able to modulate the response leading to cell death. Based on the results reported here, it is proposed that PUA act as such factors, which induce modifications of the intracellular ROS levels, which then result in a differential activation of ScDSP genes. The successive reaction depends then on the amount of ROS produced and possibly on the cell physiological and growth status. This scenario is supported by the observation that the increase in DSP gene expression in our experiments was not linearly correlated to PUA concentrations. While it is possible that the experimental design was not appropriate to detect sudden peaks occurring at intermediate time points, it is unlikely that these lasted for shorter than $1 \mathrm{~h}$. Indeed, when a further time point at 30 min after inoculation was included, the expression levels were not even comparable to the highest expression measured during the experiments (data not shown). Therefore,

\section{a}

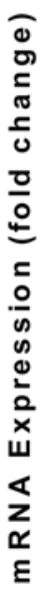

1000
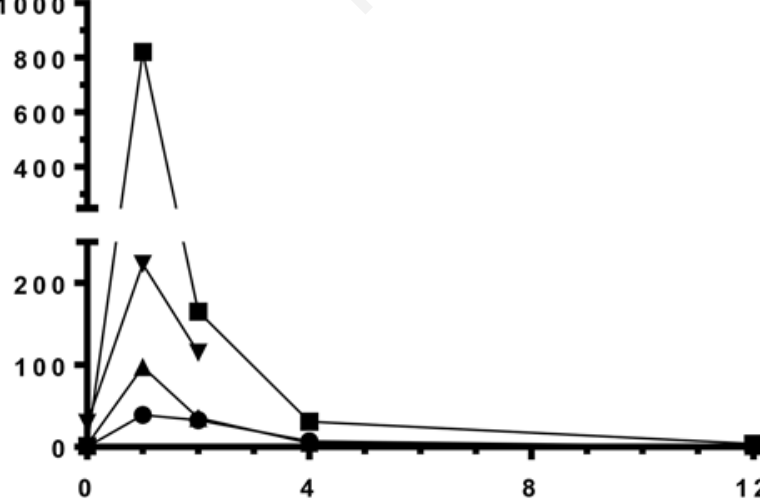

b

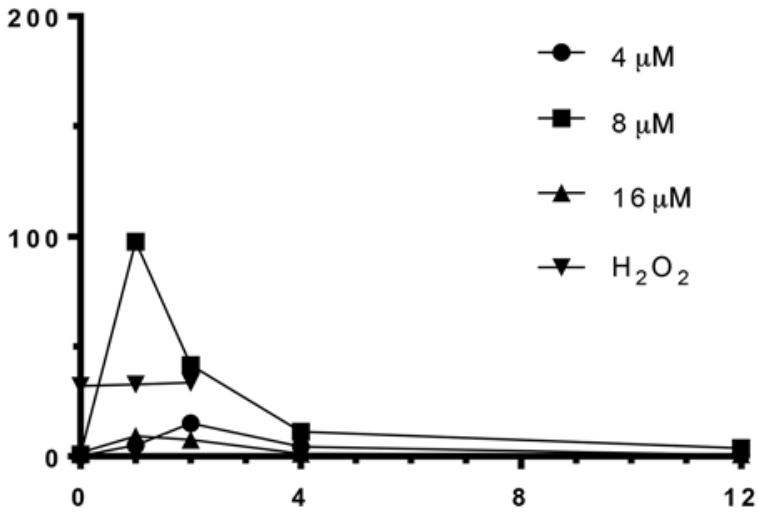

Incubation time (hours)

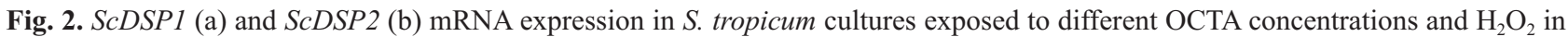
LE cultures. Data are expressed as mean of fold changes of mRNA abundance (relative to control) from technical triplicates. The experiments were repeated at least twice. 
considering that a burst in ROS production always occurred 20 min after exposure to all the different PUA tested, it is possible to conclude that the concentration of $8 \mu \mathrm{M}$ OCTA represents a threshold value below which the cell activates defences mechanisms to cope with the related oxidative stress. (Chung et al., 2005, 2008).

Based on the results reported here, it is suggested that in the case of PUA-induced chemical stress, DSP genes expression is regulated by ROS. Although we cannot exclude a role for NO in the process, data from the congeneric $S$. marinoi show that ROS and not NO have a main role in the response to PUA in this diatom and probably in the congeneric S. tropicum (Gallina et al., 2014). In addition, considered that $D S P$ is reported to be a $\mathrm{Ca}^{2+}$ regulated protein (Chung et al., 2005), it is then possible that in S. tropicum ROS are acting as $\mathrm{Ca}^{2+}$ mobilizing agents, as also happens in other biological systems (Gonzalez et al., 2002; Mallilankaraman et al., 2011; Wendehenne et al., 2004).

\section{CONCLUSIONS}

The reported findings are only preliminary and need to be substantiated by further experiments aimed at proving a clear connection between ROS and DSP expression. In addition, direct data on PCD activation have to be acquired, possibly using the genomic approach used by Lauritano et al., (2015). However, based on these preliminary results and combining them on the vast literature on PUA in diatoms, we propose that in Skeletonema spp. the ROS

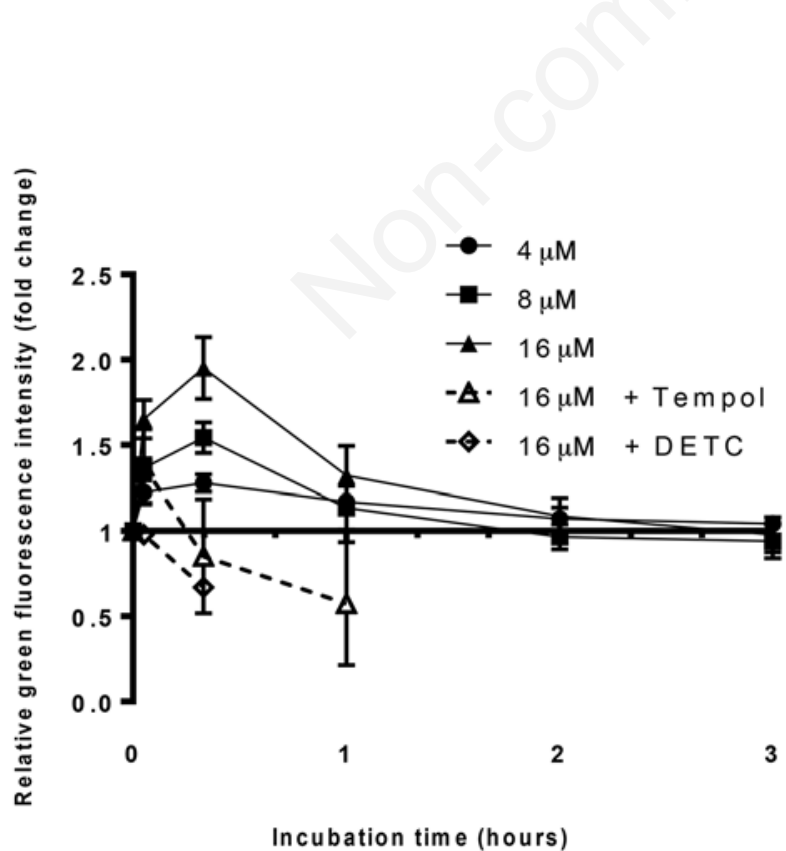

Fig. 3. ROS production in S. tropicum exposed to different concentrations of OCTA. Data are values of DHR123-derived green fluorescence normalized to the control values. Data are means \pm SD from three biological replicates. downstream response to PUA activates either a protection pathway (i.e., antioxidant defence) or a cell death cascade either through activation of specific genes or through nongenetically controlled cell death, depending on the PUA used, its concentration, the time of exposure, the concentration of ROS produced and the physiological state of the cell. This has important implications for bloom regulation and population dynamics and induction of cell lysis, as instance, immediately after the peak stage of a diatom bloom, when cell concentrations are highest but environmental factors become limiting and do not support further growth (Vanboekel et al., 1992).

It has been proposed that the evolution of PCD in unicellular organisms as a byproduct of selection might be explained by the possibility that PCD could be a maladaptive stress-induced process that can be selected under certain conditions to benefit only some organisms or part of a population (Nedelcu et al., 2010). As related to this concept, if an intrapopulation signal (e.g., PUA) triggers the production of PCD-inducing signal (e.g., ROS), and if this intrapopulation signal-dependent death is beneficial for a part of the population (for instance, by fitting cell density to the environmental conditions), then PCD could be adaptively selected for and consequently evolve into altruistic adaptation (Nedelcu et al., 2010). This hypothesis needs to be tested in situ, where PCD has been shown to exist, for instance in reaction to a viral attack (Bidle et al. 2007), supporting its role as population regulatory mechanism, or, triggering the production of survival forms such as cysts or resting stages, using high ROS levels as signals (Vardi et al., 1999), so to assure perpetuation of the species later on, when the environment conditions become favourable again (McQuoid et al., 2002).

\section{ACKNOWLEDGMENTS}

AAG deeply acknowledges SH Hung and SF. Wang for their assistance during experiments and technical support. Travel fund for AAG has been supported by the National Science Council of Taiwan (NSC) through the Summer Program for Italian Graduate Students fellowship. AAG has been supported by a SZN-OU PhD fellowship. Materials for this study were partly supported by the Taiwan National Science Council (NSC 99-2611-M-019 -014-MY2).

\section{REFERENCES}

Aldsworth TG, Sharman RL, Dodd CER, 1999. Bacterial suicide through stress. Cell. Mol. Life Sci. 56: 78-383.

Andrianasolo EH, Haramaty L, Degenhardt K, Mathew R, White E, Lutz R, Falkowski P, 2007. Induction of apoptosis by diterpenes from the soft coral Xenia elongata. J. Nat. Prod. 70:1551-1557. 
Armbrust EV, 2009. The life of diatoms in the world's oceans. Nature 459:185-192.

Berges JA, Falkowski PG, 1998. Physiological stress and cell death in marine phytoplankton: Induction of proteases in response to nitrogen or light limitation. Limnol. Oceanogr. 43:129-135.

Bidle KD, Bender SJ, 2008. Iron starvation and culture age activate metacaspases and programmed cell death in the marine diatom Thalassiosira pseudonana. Eukaryot. Cell 7:223-236.

Bidle KD, Falkowski PG, 2004. Cell death in planktonic, photosynthetic microorganisms. Nat. Rev. Microbiol. 2:643-655.

Bidle KD, Haramaty L, Ramos JBE, Falkowski P, 2007. Viral activation and recruitment of metacaspases in the unicellular coccolithophore, Emiliania huxleyi. P. Natl. Acad. Sci. USA 104:6049-6054.

Butow BJ, Wynne D, TelOr E, 1997. Antioxidative protection of Peridinium gatunense in Lake Kinneret: seasonal and daily variation. J. Phycol. 33:780-786.

Casotti R, Mazza S, Brunet C, Vantrepotte V, Ianora A, Miralto A, 2005. Growth inhibition and toxicity of the diatom aldehyde 2-trans, 4-trans-decadienal on Thalassiosira weissflogii (Bacillariophyceae). J. Phycol. 41:7-20.

Cervia D, Di Giuseppe G, Ristori C, Martini D, Gambellini G, Bagnoli P, Dini F, 2009. The secondary metabolite euplotin C Induces apoptosis-like death in the marine ciliated protist Euplotes vannus. J. Eukaryot. Microbiol. 56:263-269.

Chandra J, Samali A, Orrenius S, 2000. Triggering and modulation of apoptosis by oxidative stress. Free Radical Biology and Medicine 29, 323-333.

Chung CC, Hwang SPL, Chang J, 2005. Cooccurrence of $S c D S P$ gene expression, cell death, and DNA fragmentation in a marine diatom, Skeletonema costatum. Appl. Environ. Microbiol. 71:8744-8751.

Chung CC, Hwang SPL, Chang J, 2008. Nitric oxide as a signaling factor to upregulate the death-specific protein in a marine diatom, Skeletonema costatum, during blockage of electron flow in photosynthesis. Appl. Environ. Microbiol. 74:6521-6527.

Costas E, Aguilera A, Gonzalezgil S, Lopezrodas V, 1993. Contact inhibition: also a control for cell proliferation in unicellular algae? Biol. Bull. 184:1-5.

Deponte M, 2008. Programmed cell death in protists. BBA Mol. Cell Res. 1783:1396-1405.

Ellegaard M, Ribeiro S, Lundholm N, Andersen TJ, Berge T, Ekelund F, Harnstrom K, Godhe A, 2013. Using the sediment archive of living dinoflagellate cysts and other protists resting stages to study dynamics through time, pp. 149-153. In: F. Marrett, J.M. Lewis and L.R. Bradely (eds.), Biological and Geological perspectives of dinoflagellates. Geological Society, London.

Evans C, Malin G, Mills GP, Wilson WH, 2006. Viral infection of Emiliania huxleyi (Prymnesiophyceae) leads to elevated production of reactive oxygen species. J. Phycol. 42:1040-1047.

Gallina AA, Brunet C, Palumbo A, Casotti R, 2014. The Effect of polyunsaturated aldehydes on Skeletonema marinoi (Bacillariophyceae): the involvement of reactive oxygen species and nitric oxide. Mar. Drugs 12:4165-4187.

Gonzalez A, Schmid A, Salido GM, Camello PJ, Pariente JA, 2002. XOD-catalyzed ROS generation mobilizes calcium from intracellular stores in mouse pancreatic acinar cells. Cell. Signal. 14:153-159.

Guillard RRL, 1975. Culture of phytoplankton for feeding marine invertebrates, pp. 29-60. In:, W. L. Smith and M.H. Chanley (eds.), Cultures of marine invertebrate animals. Plenum Publishing Co., New York.

Ischiropoulos H, Gow A, Thom SR, Kooy NW, Royall JA, Crow JP, 1999. Detection of reactive nitrogen species using 2,7dichlorodihydrofluorescein and dihydrorhodamine 123. In: J.N. Abelson, M.I. Simon and H. Sies (eds.). Methods in enzymology - Nitric oxide Part C - Biological and antioxidant activities, vol. 301. Academic Press, San Diego.

Jamers A, Lenjou M, Deraedt P, Van Bockstaele D, Blust R, de Coen W, 2009. Flow cytometric analysis of the cadmiumexposed green alga Chlamydomonas reinhardtii (Chlorophyceae). Eur. J. Phycol. 44, 541-550.

Jimenez C, Capasso JM, Edelstein CL, Rivard CJ, Lucia S, Breusegem S, Berl T, Segovia M, 2009. Different ways to die: cell death modes of the unicellular chlorophyte Dunaliella viridis exposed to various environmental stresses are mediated by the caspase-like activity DEVDase. J. Exp. Bot. 60:815-828.

Jones DP, 2008. Radical-free biology of oxidative stress. Am. J. Physiol. Cell Physiol. 295:C849-C868.

Kuwabara M, Asanuma T, Niwa K, Inanami O, 2008. Regulation of cell survival and death signals induced by oxidative stress. J. Clin. Biochem. Nutr. 43:51-57.

Lam E, 2008. Programmed cell death in plants: orchestrating an intrinsic suicide program within walls. Crit. Rev. Plant Sci. 27:413-423.

Lauritano C, Orefice I, Procaccini G, Romano G, Ianora A, 2015. Key genes as stress indicators in the ubiquitous diatom Skeletonema marinoi. BMC Genomics 16:411.

Luan S, Kudla J, Rodriguez-Concepcion M, Yalovsky S, Gruissem W, 2002. Calmodulins and calcineurin B-like proteins: calcium sensors for specific signal response coupling in plants. Plant Cell 14:S389-S400.

Mallilankaraman K, Gandhirajan RK, Hawkins BJ, Madesh M, 2011. Visualization of vascular $\mathrm{Ca}^{2+}$ signaling triggered by paracrine derived ROS. J. Vis. Exp. DOI: 10.3791/3511

Martindale JL, Holbrook NJ, 2002. Cellular response to oxidative stress: signaling for suicide and survival. J. Cell. Physiol. 192:1-15.

McQuoid MR, Godhe A, Nordberg K, 2002. Viability of phytoplankton resting stages in the sediments of a coastal Swedish fjord. Eur. J. Phycol. 37:191-201.

Means AR, Dedman JR, 1980. Calmodulin - an intracellular calcium receptor. Nature 285:73-77.

Nedelcu AM, Driscoll WW, Durand PM, Herron MD, Rashidi A, 2010. On the paradigm of altruistic suicide in the unicellular world. Evolution 65:3-20.

Pippen EL, Nonaka M, 1958. A convenient method for synthesizing normal aliphatic 2,4-dienals. J. Org. Chem. 23:15801582.

Ribalet F, Berges JA, Ianora A, Casotti R, 2007. Growth inhibition of cultured marine. phytoplankton by toxic algal-derived polyunsaturated aldehydes. Aquat. Toxicol. 85:219-227.

Rockenfeller P, Madeo F, 2008. Apoptotic death of ageing yeast. Exp. Gerontol. 43: 876-881.

Scherz-Shouval R, Elazar Z, 2007. ROS, mitochondria and the 
regulation of autophagy. Trends Cell Biol. 17:422-427.

Segovia M, 2011. Cell death or survival in the unicellular chlorophyte Dunaliella: the role of metacaspases and caspase-like proteases. Eur. J. Phycol. 46:32-33.

Segovia M, Berges JA, 2009. Inhibition of caspase-like activities prevents the appearance of reactive oxygen species and dark-induced apoptosis in the unicellular chlorophyte Dunaliella tertiolecta. J. Phycol. 45:1116-1126.

Simon HU, Haj-Yehia A, Levi-Schaffer F, 2000. Role of reactive oxygen species (ROS) in apoptosis induction. Apoptosis 5:415-418.

Thamatrakoln K, Bailleul B, Brown CM, Gorbunov MY, Kustka AB, Frada M, Joliot PA, Falkowski PG, Bidle KD, 2013. Death-specific protein in a marine diatom regulates photosynthetic responses to iron and light availability. P. Natl. Acad. Sci. USA 110:20123-20128.

Thamatrakoln K, Korenovska O, Niheu AK, Bidle KD, 2012. Whole-genome expression analysis reveals a role for deathrelated genes in stress acclimation of the diatom Thalassiosira pseudonana. Environ. Microbiol. 14:67-81.

Thibane VS, Ells R, Hugo A, Albertyn J, van Rensburg WJJ, Van Wyk PWJ, Kock JLF, Pohl CH, 2012. Polyunsaturated fatty acids cause apoptosis in C. albicans and C. dubliniensis biofilms. Biochim. Biophys. Acta 1820.1463-1468.

Vanboekel WHM, Hansen FC, Riegman R, Bak RPM, 1992. Lysis-induced decline of a Phaeocystis spring bloom and coupling with the microbial food web. Mar. Ecol.-Progr. Ser. 81:269-276.

Vardi A, Berman-Frank I, Rozenberg T, Hadas O, Kaplan A, Levine A, 1999. Programmed cell death of the dinoflagellate
Peridinium gatunense is mediated by $\mathrm{CO}_{2}$ limitation and oxidative stress. Curr. Biol. 9:1061-1064.

Vardi A, Bidie KD, Kwityn C, Hirsh DJ, Thompson SM, Callow JA, Falkowski P, Bowler C, 2008. A diatom gene regulating nitric-oxide signaling and susceptibility to diatom-derived aldehydes. Curr. Biol. 18:895-899.

Vardi A, Eisenstadt D, Murik O, Berman-Frank I, Zohary T, Levine A, Kaplan A, 2007. Synchronization of cell death in a dinoflagellate population is mediated by an excreted thiol protease. Environ. Microbiol. 9:360-369.

Vardi A, Formiggini F, Casotti R, De Martino A, Ribalet F, Miralto A, Bowler C, 2006. A stress surveillance system based on calcium and nitric oxide in marine diatoms. PLoS Biol. 4:411-419.

Vardi A, Schatz D, Beeri K, Motro U, Sukenik A, Levine A, Kaplan A, 2002. Dinoflagellate-cyanobacterium communication may determine the composition of phytoplankton assemblage in a mesotrophic lake. Curr. Biol. 12:1767-1772.

Vardi A, Van Mooy BAS, Fredricks HF, Popendorf KJ, Ossolinski JE, Haramaty L, Bidle KD, 2009. Viral glycosphingolipids induce lytic infection and cell death in marine phytoplankton. Science 326:861-865.

Wendehenne D, Durner J, Klessig DF, 2004. Nitric oxide: a new player in plant signalling and defence responses. Curr. Opin. Plant Biol. 7:449-455.

Wichard T, Poulet SA, Halsband-Lenk C, Albaina A, Harris R, Liu DY, Pohnert G, 2005. Survey of the chemical defence potential of diatoms: screening of fifty one species for alpha,beta,gamma,delta-unsaturated aldehydes. J. Chem. Ecol. 31:949-958. 